\title{
Lasers in Use: preparing primary students for the future
}

\section{Karen Giesler}

Karen Giesler, "Lasers in Use: preparing primary students for the future," Proc. SPIE 9663, Eighth International Topical Meeting on Education and Training in Optics and Photonics, 96631G (6 October 2003); doi: $10.1117 / 12.2208501$

SPIE Event: Eighth International Topical Meeting on Education and Training in Optics and Photonics, 2003, Tucson, Arizona, United States 


\title{
"Lasers in Use" - preparing primary students for the future
}

\author{
Karen Giesler \\ Center for Creative Learning - Rockwood School District, 265 Old State Road, Ellisville, MO 63021 \\ telephone: 636-207-2579; fax: 636-207-2584; e-mail: cct07@rockwood.k12.mo.us
}

\begin{abstract}
Lasers in Use," winner of the 2002 National Association for Gifted Children's exemplary curriculum award, captivates the interest of primary grade students. The abstract and complex concepts, interesting and unique applications, and exciting potential of lasers motivates the author's students to "think like scientists" as they experiment, question, and discover.

(C)2003 Optical Society of America

OCIS codes: (000.2060) Education
\end{abstract}

"Lasers in Use" is an accelerated curriculum that delivers rigorous content interwoven with scientific process skills and involves active student involvement in the learning process. The topic of lasers is engaging because it is a current, high interest topic containing complex concepts, interesting applications and exciting potential. The goals of the unit are to enable students to: gain an understanding and appreciation of the properties of light and its many uses; analyze and evaluate applications of lasers; predict future applications of laser technology; evaluate the impact of laser technology on the future; and assess the interactions between science, technology, and society. The integrated curriculum employs hands-on activities, experiments, simulations, discussion, debate, and research to equip young students with an understanding of the scientific principles of white light and lasers and their applications. Following laser safety certification, students experiment to discover how lasers work, analyze white light and laser light to identify their similarities and differences, and develop new laser technologies that must be safe and technically correct while solving class identified problems. These investigations are designed to challenge the students to think like scientists. The focus is on the students' ability to explain their scientific reasoning, support and defend their positions, and evaluate information as an educated consumer. "Lasers in Use," is aligned with the Missouri "Show Me Standards," National Science Standards and the Rockwood School District's Core Curriculum Objectives. 